The New Politics of British Trade Unionism 
By the same author

The CBI (with W. Grant)

Abortion Politics (with J. Chambers)

Private Members' Bills (with M. Read) 


\section{The New Politics of British Trade Unionism}

\section{Union Power and the Thatcher Legacy}

\section{David Marsh}

Department of Politics

University of Strathclyde

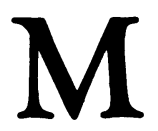

MACMILLAN 
All rights reserved. No reproduction, copy or transmission of this publication may be made without written permission.

No paragraph of this publication may be reproduced, copied or transmitted save with written permission or in accordance with the provisions of the Copyright, Designs and Patents Act 1988, or under the terms of any licence permitting limited copying issued by the Copyright Licensing Agency, 90 Tottenham Court Road, London W1P 9HE.

Any person who does any unauthorised act in relation to this publication may be liable to criminal prosecution and civil claims for damages.

First published 1992 by

THE MACMILLAN PRESS LTD

Houndmills, Basingstoke, Hampshire RG21 2XS

and London

Companies and representatives

throughout the world

ISBN 978-0-333-49301-4 ISBN 978-1-349-21921-6 (eBook)

DOI 10.1007/978-1-349-21921-6

A catalogue record for this book is available from the British Library.

Reprinted 1993 
To Holly, who, I' $m$ sure, will do better 


\section{Contents}

List of Tables $\quad$ xi

Acknowledgements xii

Abbreviations xiii

Introduction xvii

1. The Historical Background 1

The Industrial Relations Act $1971 \quad 10$

Conclusion $\quad 21$

2. Union Power Before $1979 \quad 23$

The changes in British unionism in the 1960s and

1970 s and their consequences for patterns of representation 24

Union/government relations before $1979 \quad 29$

The trade unions' access to the political sphere 35

Trade union power in Britain before 1979

Conclusion $\quad 52$

3. The Origins, Development and Content of the

Conservative Legislation $\quad 54$

The development of Conservative industrial relations $\quad 54$

policy in opposition, 1974-9

The Winter of Discontent $\quad 59$

The Conservatives in power: the triumph of 64 individualism

The legislative onslaught: its scope and content $\quad 74$

$\begin{array}{ll}\text { Conclusion } & 80\end{array}$ 
4. Using the Legislation: An Employer's Onslaught?

The operation of the Conservative Government's

legislation

The use of the law of contract

The policing of industrial relations and the use of the criminal law

The indirect effect of legislation

5. The Unions' Political Role: Relations with the

Conservative Government, 1979-90

The unions' access to government

Influencing government legislation

A strike with political resonance

The unions' role in policy-making and implementation: the case of youth employment policy

The European dimension

Conclusion

6. Trade Unions and the Labour Party

Trade unions and constitutional reform, 1979-83

Trade unionists' voting behaviour and political attitudes

Links between the Labour Party and the trade unions

The changing sectoral composition of the TUC

The political fund ballots

Beyond the ballots

The Labour Party Policy Review 158

Conclusion

7. The Changing Economic Context 164

The changing economic structure 164

The decline in union membership 169

New technology 171

Flexibilisation $\quad 176$

Changes in economic and labour market policy 183

$\begin{array}{ll}\text { Conclusion } & 188\end{array}$ 
8. Shop-floor Industrial Relations: The Private Sector 191 Changes in shop-floor industrial relations in the private sector 191

Explaining the changes $\quad 207$

Conclusion 213

9. Shop-floor Industrial Relations: The Public Sector 215 The aggregate pattern 216

Industrial relations in particular sections of the public sector

Privatisation

231

Explaining the changes 235

Conclusion 236

10. Thatcherism and industrial relations 238

Thatcherism and industrial relations 239

Thatcherism and the top-down view of policymaking

Bibliography 250

Index 


\section{List of Tables}

1.1 Changing industrial relations proposals/legislation, 1969-90: the major features

1.2 Applications to the National Industrial Relations

Court for relief from unfair industrial practices:

1.1(a) by sector; 1.1 (b) by size

2.1 Changes in the membership of TUC affiliated unions, 1970-89

2.2 Union membership, 1974-89

2.3 Trade-union-sponsored MPs, 1955-87

3.1 Public opinion on government proposals/

legislation on trade unions, 1969-84

3.2 The main features of the Thatcher Government legislation

3.3 The step-by-step approach: a cumulative process

4.1 The use of injunctions in industrial relations cases, 1980-89

4.2 Sectoral distribution of injunctions, 1980-87 89

4.3 Injunctions brought by size of company, 1980-88 90

4.4 The use of the criminal law in the 1984-5 miners' strike in England and Wales

5.1 Number and type of contact between government and unions, 1976-84 and 1988

6.1 Class, union membership and vote, 1964-87 146

6.2 Attitudes of trade unionists 148

7.1 Changing economic indicators, 1979-89 165

7.2(a) Employees in employment, 1970-88 166

7.2(b) Employees in employment, 1979-88 167 


\section{Acknowledgements}

George Taylor, Andrew Taylor and Gerry Taylor all provided helpful comments on chapters of this book - in fact you might say it was 'taylor-made'. I'd like to thank Jenny Mortimer, Linda Day and, especially, Hazel Burke for turning a handwritten manuscript into a legible text - I promise to learn to use my word processor for the next one.

DAVID MARSH 


\section{Abbreviations}

$\begin{array}{ll}\text { ABP } & \text { Associated British Ports } \\ \text { ACAS } & \begin{array}{l}\text { Advisory Conciliation and Arbitration Service } \\ \text { Association of Cinematograph, Television and Allied } \\ \text { ACTT }\end{array} \\ \begin{array}{ll}\text { Technicians } \\ \text { AEU }\end{array} & \text { Amalgamated Engineering Union } \\ \text { (Formerly AUEW) (Amalgamated Union of Engineering Workers) } \\ \text { AJ } & \text { After Japan } \\ \text { APEX } & \text { Association of Professional, Executive, Clerical and } \\ & \text { Computer Staff } \\ \text { ASLEF } & \text { Associated Society of Locomotive Engineers and } \\ & \text { Firemen } \\ \text { ASTMS } & \text { Association of Scientific, Technical and Managerial } \\ & \text { Staff } \\ \text { BG } & \text { British Gas } \\ \text { BIFU } & \text { Banking, Insurance and Finance Union } \\ \text { BR } & \text { British Rail } \\ \text { BT } & \text { British Telecommunications } \\ \text { CBI } & \text { Confederation of British Industry } \\ \text { CLP } & \text { Constituency Labour Party } \\ \text { CLPD } & \text { Campaign for Labour Party Democracy } \\ \text { CLV } & \text { Campaign for a Labour Victory } \\ \text { COHSE } & \text { Confederation of Health Service Employees } \\ \text { CPSA } & \text { Civil and Public Services Association } \\ \text { CTU } & \text { Conservative Trade Unionists } \\ \text { DEmp } & \text { Department of Employment } \\ \text { DHSS } & \text { Department of Health and Social Security } \\ \text { EC } & \text { European Community } \\ \text { EEF } & \text { Engineering Employer's Federation } \\ & \end{array}$




\begin{tabular}{|c|c|}
\hline EETPU & $\begin{array}{l}\text { Electrical, Electronic, Telecommunication and } \\
\text { Plumbing Union }\end{array}$ \\
\hline ESC & $\begin{array}{l}\text { Economic and Social Council (of the European } \\
\text { Community) }\end{array}$ \\
\hline ET & Employment Training \\
\hline FBU & Fire Brigade Union \\
\hline GMBATU & $\begin{array}{l}\text { General, Municipal, Boilermakers and Allied Trades } \\
\text { Union }\end{array}$ \\
\hline HSC & Health and Safety Commission \\
\hline ICCUS & Inns of Court Conservative and Unionist Society \\
\hline IDS & Income Data Services \\
\hline IPCS & Institution of Professional Civil Servants \\
\hline ITB & Industrial Training Board \\
\hline JIC & Just-in-case \\
\hline JIT & Just-in-time \\
\hline LACSAB & $\begin{array}{l}\text { Local Authorities Conditions of Service Advisory } \\
\text { Board }\end{array}$ \\
\hline MDHCS & Mersey Docks and Harbour Corporation \\
\hline MSC & Manpower Services Commission \\
\hline MSF & Manufacturing, Science and Finance Union \\
\hline NALGO & National Association of Local Government Officers \\
\hline NAPE & National Association of Port Employers \\
\hline NCB & National Coal Board \\
\hline NDLS & National Dock Labour Scheme \\
\hline NEC & National Executive Committee \\
\hline NEDC & National Economic Development Council \\
\hline NEDO & National Economic Development Office \\
\hline NGA & National Graphical Association \\
\hline NHS & National Health Service \\
\hline NIRC & National Industrial Relations Court \\
\hline NJC & National Joint Council \\
\hline NRC & National Reporting Centre \\
\hline NTA & New Technology Agreement \\
\hline NUJ & National Union of Journalists \\
\hline NUM & National Union of Mineworkers \\
\hline NUPE & National Union of Public Employees \\
\hline NUR & National Union of Railwaymen \\
\hline NUT & National Union of Teachers \\
\hline PLA & Port of London Authority \\
\hline PLP & Parliamentary Labour Party \\
\hline POEU & Post Office Engineering Union \\
\hline
\end{tabular}




\begin{tabular}{|c|c|}
\hline PRG & Policy Review Group \\
\hline PSBR & Public Sector Borrowing Requirement \\
\hline PSI & Policy Studies Institute \\
\hline SDP & Social Democratic Party \\
\hline SOGAT (82) & Society of Graphical and Allied Trades \\
\hline SUA & Single Union Agreement \\
\hline TA & Training Agency \\
\hline TASS & $\begin{array}{l}\text { Technical Administrative and Supervisory Section of } \\
\text { the AUEW }\end{array}$ \\
\hline TC & Training Council \\
\hline TEC & Training Enterprise Council \\
\hline TGWU & Transport and General Workers Union \\
\hline TUC & Trades Union Congress \\
\hline TUCC & Trade Union Coordinating Committee \\
\hline TUFL & Trade Unions for Labour \\
\hline TULV & Trade Unions for a Labour Victory \\
\hline TULRA & Trade Union and Labour Relations Act \\
\hline UCATT & Union of Combustion, Allied Trades and Technicians \\
\hline UCW & Union of Communication Workers \\
\hline USDAW & Union of Shop, Distributive and Allied Workers \\
\hline WIRS & Workplace Industrial Relations Survey \\
\hline YOP & Youth Opportunities Programme \\
\hline YT & Youth Training \\
\hline YTS & Youth Training Scheme \\
\hline
\end{tabular}




\section{Introduction}

Without exception, journalistic assessments of Mrs Thatcher's achievements in office, following her departure as Prime Minister in November 1990, highlighted her industrial relations policy or, more graphically; her 'defeat' of the trade unions, as a major, perhaps the major, achievement of Thatcherism.

The Guardian's analysis was typical:

The overdue reform of the trade unions will stand among the most positive legacies of the Thatcher era.

(Keith Harper, Guardian, 23 November 1990)

Of course it is not only journalists who have emphasised Mrs Thatcher's success in this field. Some of the most well-known British political scientists have stressed the curbing of union power. So, Kavanagh argues:

The government's legislation on industrial relations and trade unions has taken hold. Here is an area where the balance of advantage has changed since 1979, from union to employers and managers and from the consultative role granted to the unions to one in which they are virtually ignored by the government.

(Kavanagh, 1987, p. 243; see also King, 1988, p. 62 and Gamble, 1988, pp. 126-7)

This view has also been shared by sociologists (Crouch, 1986, p. 131), economists (Minford, 1988, p.99), historians (Holmes, 1985, p. 214) and even some students of industrial relations (Roberts, 1989, p. 78). 
The argument of Kavanagh and others is fairly straightforward. In 1979 the Conservative Government had a limited number of aims. It wished to: remove the unions' role in the policy-making process; assert its authority, and therefore its image of governing competence, by standing up to the unions; change the attitudes and strategies of unions instilling a New Realism; and alter the balance on the shop floor in favour of management. Overall, the government wanted to weaken the unions' position in relation to both government and employers; to restrict what many observers saw as their excessive power.

Political scientists, like Kavanagh, argue that the Conservative Government has achieved these aims but, in so far as they present empirical evidence to support such a conclusion, they concentrate upon the changes in the relations between the unions and government. Their argument emphasises three changes. First, unions are no longer involved in policy-making and have had no influence on legislation. Second, the government has been able to transform the legislative framework within which unions have operated and has had limited problems of compliance from unions. This 'success' is contrasted with the fate of the 1971 Industrial Relations Act which union non-compliance turned into a virtual dead letter by the time it was repealed. Third, the government successfully resisted a number of public sector strikes, notably of course, the 1984-5 miners' strike. This reinforced its image of governing competence and helped confirm the triumph of New Realism in the trade union movement. The political scientists pay little or no attention to changes in shopfloor industrial relations.

Of course, not everyone accepts the Kavanagh view. The industrial relations literature, particularly, is critical of the notion that the Thatcher Government has transformed industrial relations. This literature concentrates upon relations between employers and unions and is mainly concerned with the role of government in so far as it sets the framework within which shop-floor industrial relations operate. Two clear points emerge from the majority of this literature. First it is argued that less has changed than Kavanagh and others claim; in particular little has altered on the shop floor (Kelly, 1987, pp. 8, 12, 14, 16-17; McIlroy, 1988, p. 233; McInnes, 1987, p. 6). Second, it is suggested that, in so far as these changes have occurred, they result more from the transformation of the occupational structure and the macroeconomy than from government policy and 
legislation (Kelly, 1987, p. 17; McIlroy, 1988; McInnes, 1987; Wedderburn, 1985, p. 33).

These two positions are significantly different and result, at least in part, from the particular interests of social scientists as compared with industrial relations specialists. Each discipline pays insufficient attention to the other's literature. The aim of this book is to present a broader and more thorough analysis dealing with the unions' relations with both government and employers by drawing on the literature from a number of disciplines. To this end I will focus upon three key questions: How much has changed in the position of unions in relation to both government and employers? Why have these changes occurred? What is likely to happen in the future?

In order to address these questions the book contains ten substantive chapters. The first chapter looks at the development of labour law throughout this century, paying most attention to the Labour Government's 1969 White Paper, In Place of Strife and the Conservative Government's 1971 Industrial Relations Act. This is crucial, as it is impossible to understand fully the particularities of the Thatcher Government's legislation, or the strategy the government adopted, without such a historical perspective. The second chapter assesses the extent of trade union power before 1979, paying particular attention to their role in the 1974-9 Labour Government. Without such an analysis it is impossible to comment on the putative decline in their power.

Having established this background, the third chapter analyses the evolution and content of the five major pieces of legislation passed by the Conservative Government; the 1980, 1982, 1988 and 1990 Employment Acts and the 1984 Trade Union Act. Of course, legislation can easily be passed by a government with a large majority. However, the legislation may not be used by employers or unions. Indeed, that is what happened, to a large extent, in the case of the 1971 Industrial Relations Act. For this reason, Chapter 4 examines the use of the Conservative legislation by employers.

Many authors emphasise that the Conservative Government has ended the cosy process of consultation and excluded the trade unions from policy-making. Chapter 5 looks at the extent to which relations between unions and government have changed since 1979. At the same time, the relationship between the trade unions and the Labour Party is crucial for any understanding of the position of unions. In Chapter 2, I look at this relationship during the key period of the 
Social Contract. Chapter 6 concentrates upon the changes in that relationship since 1979, changes which it is necessary to understand if we are to attempt any assessment of the likely future of unions.

In Chapter 7 I examine the economic changes which have contributed to the decline in the unions' position. Subsequently, Chapters 8 and 9 deal with the most important question, as far as industrial relation specialists are concerned: how far have things changed on the shop floor? Chapter 8 looks at changes in the private sector, while Chapter 9 considers the public sector.

The final chapter initially presents a summary of the conclusions of the book. Subsequently, however, I raise the broader question of what this case study of one area of policy-making reveals more generally about the influence of Thatcherism on British politics. 